\title{
Is legal protection sufficient to ensure plant conservation? The Italian Red List of policy species as a case study
}

\author{
Graziano Rosit, Simone Orsenigo, Chiara Montagnani, Giuseppe Fenu \\ Domenico Gargano, Lorenzo Peruzzi, Robert P. Wagensommer \\ Bruno Foggi, Gianluigi Bacchetta, Gianniantonio Domina, Fabio Conti \\ Fabrizio Bartolucci, Matilde Gennai, Sonia Ravera, Annalena Cogoni \\ Sara Magrini, Rodolfo Gentili, Miris Castello \\ CARLO BLASi and Thomas ABELI
}

\begin{abstract}
The conservation of species listed in the Bern Convention and European Directive 1992/43/EEC (so-called policy species) is mandatory for European Union (EU) countries. We assessed the conservation status of Italian policy species, based on the IUCN categories and criteria,
\end{abstract}

Graziano Rossi*, Simone Orsenigo* (Corresponding author), Chiara Montagnanit, Giuseppe Fenu $\neq, \mathcal{S}$, Domenico Garganog, Lorenzo Peruzzil|, Robert P. Wagensommer ${ }^{* *}$, Bruno Foggi $\dagger$, Gianluigi Bacchetta $\$$, Gianniantonio Dominass, Fabio Contigg, Fabrizio Bartoluccigg, Matilde Gennait†, Sonia Ravera \|\| , Annalena Cogoni**, Sara Magrinit ${ }^{*} \dagger,\|\| \|$,

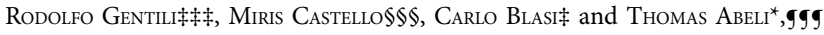
Società Botanica Italiana, Via G. La Pira 4, 50121 Firenze, Italy

E-mail simone.orsenigo@unipv.it

*Also at: Dipartimento di Scienze della Terra e dell'Ambiente, Università degli Studi di Pavia, Pavia, Italy

$\dagger$ Also at: Dipartimento di Scienze della Terra, dell'Ambiente e della Vita, Università degli Studi di Genova, Genova, Italy

¥Also at: Dipartimento di Biologia Ambientale, Università 'La Sapienza' di Roma, Roma, Italy

$\S$ Also at: IUCN/SSC Mediterranean Plant Specialist Group

Also at: Dipartimento di Biologia, Ecologia e Scienze della Terra, Università della Calabria, Arcavacata di Rende (CS), Italy

||Also at: Dipartimento di Biologia, Università degli Studi di Pisa, Pisa, Italy

${ }^{*}$ Also at: Dipartimento di Scienze Biologiche, Geologiche e Ambientali, Università degli Studi di Catania, Catania, Italy

$\dagger \uparrow$ Also at: Dipartimento di Biologia, Università degli Studi di Firenze, Firenze, Italy

¥Also at: Dipartimento di Scienze della Vita e dell’Ambiente, Centro Conservazione Biodiversità, Sezione Botanica, Università degli Studi di Cagliari, Cagliari, Italy

$\$ \S$ Also at: Dipartimento di Scienze Agrarie e Forestali, Università degli Studi di Palermo, Palermo, Italy

ggAlso at: Scuola di Scienze Ambientali, Università degli Studi di CamerinoCentro Ricerche Floristiche dell'Appennino, P.N. del Gran Sasso e Monti della Laga, Italy

|| ||Also at: Dipartimento di Bioscienze e Territorio, Università degli Studi del Molise, Pesche (IS), Italy

${ }^{* * *}$ Also at: Dipartimento di Scienze della Vita e dell'Ambiente - Sezione Botanica ed Orto Botanico, Università degli Studi di Cagliari, Cagliari, Italy †† Also at: Erbario e Banca del Germoplasma della Tuscia, Università degli Studi della Tuscia, Viterbo, Italy

㭋Also at: Dipartimento di Scienze della Terra e dell'Ambiente, Università Milano-Bicocca, Milano, Italy

$\$ \S \S$ Also at: Dipartimento di Scienze della Vita, Università degli Studi di Trieste, Trieste, Italy

gggAlso at: IUCN/SSC Reintroduction Specialist Group

|| || ||Also at: IUCN/SSC Orchid Specialist Group

Received 3 September 2014. Revision requested 24 October 2014.

Accepted 20 January 2015. First published online 28 April 2015. to evaluate the effectiveness of existing protection measures at the national level. Among the 203 vascular plants, bryophytes and lichens evaluated, $41.9 \%$ are categorized as threatened, and one is already extinct, indicating that the protection measures for policy species are inadequate. Our results for the Italian policy species are consistent with those of an assessment at the EU level. Conservation priorities should be established at both the national and regional scales. An effective conservation strategy is needed, and in situ and ex situ actions focused on threatened species should be promoted.

Keywords Bern Convention, conservation priorities, extinction risk, Habitats Directive 1992/43/EEC, in situ/ex situ conservation, Italian flora, IUCN Red List, threatened policy species

To view supplementary material for this article, please visit http://dx.doi.org/10.1017/So03060531500006X

\section{Introduction}

7 he protection of the Italian flora has been addressed 1 only by laws ratifying international agreements or European Union (EU) directives (Rossi et al., 2014a), and acts adopted by some administrations at local level (e.g. LR 10/2008, Lombardy Region; LR 45/2009, Valle d'Aosta Region; LR 9/2007, Friuli Venezia Giulia Region). The 1982 Bern Convention on the Conservation of European Wildlife and Natural Habitats, and the Habitats Directive (1992/43/EEC) are therefore the most important environmental regulations at the $\mathrm{EU}$ and national levels. Monitoring and reporting the conservation status of species listed in the Habitats Directive is mandatory for all EU member states. The EU has also established preferential funds targeted for the conservation of these species and their habitats (i.e. the LIFE Programme). These species (known as policy species) represent a heterogeneous group legally protected at the EU and national levels 
based on their supposed rarity, threatened status, and/or socioeconomic importance.

Using the IUCN Red List criteria to assess the extinction risk of policy taxa is a suitable and rapid method for verifying the effectiveness of national and EU conservation policies (Moreno Saiz et al., 2003). The IUCN Red List procedure assesses the relative extinction risk of threatened taxa (IUCN, 2013). Globally, this procedure is the most widely used protocol for species risk assessment (Rodrigues et al., 2006) because it facilitates objective, replicable and flexible assessments (Gärdenfors et al., 2001; De Grammont \& Cuarón, 2006). Although the IUCN Red List criteria were developed for global assessments they are also widely used at regional (subglobal) scales (Gärdenfors et al., 2001; IUCN, 2012a), as exemplified by the numerous national and subnational Red Lists that have been produced in the last decade (e.g. Király, 2007; Tsintides et al., 2007; Moreno Saiz, 2008; Kålås et al., 2010; Rassi et al., 2010; Turis et al., 2014; Foggi et al., 2015). Regional assessments of species extinction risk provide a basis for conservation planning and allocation of funds, not only at the administrative level (e.g. Bilz et al., 2011) but also at a given biogeographical scale (Gentili et al., 2011). For these reasons up-to-date Red Lists are an important starting point for further conservation action and may provide useful information for monitoring changes in the conservation status of species. Despite these advantages relatively few taxa listed in the European policy instruments have been assessed recently in Italy using the latest version of the IUCN categories and criteria (version 3.1; e.g. de Montmollin \& Strahm, 2005; Fenu et al., 2011, 2012), and the currently available national and regional reports consider only few policy species and are based on older protocols (Conti et al., 1992, 1997).

Here we present the results of a national assessment, based on IUCN guidelines (IUCN, 2012a,b), of the conservation status of all Italian policy species, comprising vascular plants, bryophytes and lichens, listed in the annexes of the Bern Convention and the Habitats Directive 1992/43/ EEC. The outcomes of Red List assessments can give an indication of the effectiveness of EU laws for the preservation of plant diversity. In particular, with this assessment we aim to identify the most threatened species and highlight threats and taxa that require urgent conservation action in Italy.

\section{Methods}

The conservation status of all the Italian policy species was assessed with the IUCN categories and criteria (IUCN, 2012b). Data on species distribution were collected from field surveys, herbarium specimens, and published and unpublished data since 2003. In some cases, for taxa occurring in stable habitats (e.g. remote forests or vertical cliffs), data since 1993 were used. All records were validated by a selected group of botanists, and revised taxonomically according to the most recent national checklist (Conti et al., 2005, 2007; Peruzzi, 2010) that incorporates the latest taxonomic updates (i.e. the Angiosperm Phylogeny Group (APG) III system). In cases where groups of species were included in the Bern Convention and Habitats Directive (e.g. at the genus level: Sphagnum L. spp., Lycopodium L. spp., Cladonia P. Browne subgenus Cladina (Nyl.) Nyl.) all of the species belonging to the genus and occurring in Italy were treated separately. The data were organized in a database, including distribution of taxa, population trends, and the main threats identified by expert-based observations, and then categorized according to the IUCN threats classification scheme (version 3.2; IUCN, 2012c). The distribution data were organized in a geo-database, in which each georeferenced record of a species was reported in a grid of $2 \times 2 \mathrm{~km}$ cells generated using ArcGIS v. 9.2 (ESRI, Redlands, USA) and superimposed on a map of Italy (Gargano, 2011). This ensured standardized calculations of Area of Occupancy, as are required under criterion B2 (IUCN, 2013). In a few cases, when reliable data on population trends or population size were available, other criteria were also applied (e.g. A, C and D; IUCN, 2012b; Rossi et al., 2013a). Following the precautionary approach suggested in Butchart et al. (2006) and the IUCN guidelines (version 9.0, 2011), species that were not recorded during the previous 3 decades but for which there remained uncertainty regarding extinction were categorized as Critically Endangered (Possibly Extinct).

\section{Results}

A total of 203 policy species were assessed, based on 10,957 georeferenced records. The taxa considered in the assessment included 60 (29.6\%) species endemic to Italy, 35 $(58.3 \%)$ of which were assigned to a threat category. The risk category for each species, and the criteria applied in each assessment, are summarized in Supplementary Table S1. One species, Aldrovanda vesiculosa $\mathrm{L}$., was categorized as extinct in Italy (Regionally Extinct). Ten species (seven vascular plants and three bryophytes) had not been recorded in recent years and were categorized as Critically Endangered (Possibly Extinct). Eighty-five taxa (41.9\%) were assigned to a risk category (Critically Endangered (Possibly Extinct), Critically Endangered, Endangered, Vulnerable; Table 1). An additional 24 species (11.8\%) were categorized as Near Threatened, and 43 species (21.2\%) were categorized as Least Concern. Fifty policy species (24.6\%), mostly bryophytes (32), were categorized as Data Deficient because the available data did not permit a robust assessment (Table 1). The assessment was based primarily on criterion $B$ because most of the data used were distribution records, and there was little information available 
TABLE 1 Numbers of EU policy plant species (grouped as vascular plants, bryophytes and lichens) present in Italy assigned to each Red List category, with the numbers of Italian endemic species in parentheses.

\begin{tabular}{lccl}
\hline & $\begin{array}{l}\text { No. of vascular } \\
\text { plants (endemic }\end{array}$ & & \\
IUCN Red List category & to Italy) & Bryophtyes & Lichens \\
\hline Regionally Extinct & 1 & 0 & 0 \\
Critically Endangered & 7 & 3 & 0 \\
$\quad$ (Possibly Extinct) & & 5 & \\
Critically Endangered & $18(11)$ & 3 & 0 \\
Endangered & $35(18)$ & 0 & 0 \\
Vulnerable & $10(6)$ & 0 & 0 \\
Near Threatened & $24(10)$ & 0 & 3 \\
Least Concern & $40(12)$ & 32 & 1 \\
Data Deficient & $17(3)$ & 43 & 8 \\
Total & $152(60)$ & & \\
\hline
\end{tabular}

on population dynamics (only 11 taxa assessed using criteria C or D).

Most of the species evaluated were affected by multiple threats (IUCN, 2012C), mainly related to human-mediated habitat modifications (Fig. 1). Threats in the major category of natural system modifications were the most frequent (30\%); these included modifications of processes underlying natural and semi-natural systems (e.g. fire, water use, degradation, abandonment). One-fifth of taxa were also threatened by human intrusion and disturbance, including recreational activities and tourism. Other significant threats included agriculture and aquaculture (10\%), which affect mainly wetlands and grasslands (i.e. intensification of grazing, inadequate agro-pastoral practices), residential and commercial development ( $7 \%)$, which affects the coastal areas of Italy, and invasive and other problematic species $(7 \%)$.

\section{Discussion}

The EU is considered to possess one of the most advanced and effective intergovernmental biodiversity policy instruments (Trouwborst, 2009) but, based on previous reports at EU level, only $17 \%$ of the species and habitats legally protected by the Habitats Directive 1992/43/EEC have a favourable conservation status (Condé et al., 2010). The data from Italy are consistent with those of a European assessment of the policy species, in which $44.9 \%$ of vascular plants were categorized as threatened (Bilz et al., 2011). There are also similarities between Europe as a whole and Italy in terms of threats, with human-mediated habitat loss, degradation and fragmentation being among the most prevalent threats (Bilz et al., 2011).

The results of this assessment indicate that significant work remains to reach the conservation targets of the Habitats Directive, the Global Strategy for Plant Conservation, and the European Strategy for Plant Conservation, and that the efforts undertaken in the last 20 years are insufficient to maintain an acceptable conservation status for many taxa. According to EU legislation the conservation of policy species is mandatory (art.8 Directive 1992/43/ EEC), and member states have full responsibility for their conservation, especially for endemic species.

This assessment revealed that the legal protection of entire groups of species (e.g. Sphagnum, Lycopodium, Cladonia subgenus Cladina) does not ensure their conservation. Because single species are not distinguished within these groups, the risk level assigned to most threatened taxa is misleadingly reduced by the contributions of less threatened species. In addition, such groups encompass species adapted to various habitats (e.g. Cladonia spp.), reducing the possibility of effective habitat-based conservation measures. Hence, the conservation approach that encompasses entire groups of taxa should be avoided and a single-taxon approach used. Conservation action plans, which currently are available only for a few taxa (Devillers-Terschuren, 1999), are required.

IUCN criterion B was the most commonly used criterion for risk categorization because of the ease of collecting distribution data. This is as a result of the lack of detailed information on population dynamics (such as number of mature individuals, population viability analysis) of the species. There is a particular problem with non-vascular taxa. Detailed occurrence data for bryophytes (i.e. Sphagnum spp.) are available only for some areas of Italy, and the population trends of these species are mostly unknown. This led to the categorization of a significant proportion of species as Data Deficient. Eleven percent of vascular plants have also been categorized as Data Deficient, indicating that further biogeographical and ecological analyses of policy species should be undertaken. As highlighted by Crain \& White (2013), continuing field and herbarium research is fundamental to confirm and update the distribution of threatened plants and to facilitate conservation of these species. Moreover, mapping plant distributions is useful for revealing localized areas most in need of attention and, given that availability of funding is often the main limitation to conservation, helps to focus attention on legal protection and targeted management for small geographical areas with relatively high levels of plant diversity (Médail \& Quézel, 1999; Laguna et al., 2003; Crain et al., 2011; Cañadas et al., 2014).

Although in situ conservation measures are the best methods for preserving plant diversity (UNEP, 2002), ex situ conservation provides an alternative method for preventing immediate extinction (UNEP, 2002; Godefroid et al., 2011a). More importance should be given to ex situ conservation in seed banks (Mattana et al., 2012; Rossi et al., 2014b), which may support further interventions requiring detailed biological and ecological knowledge 


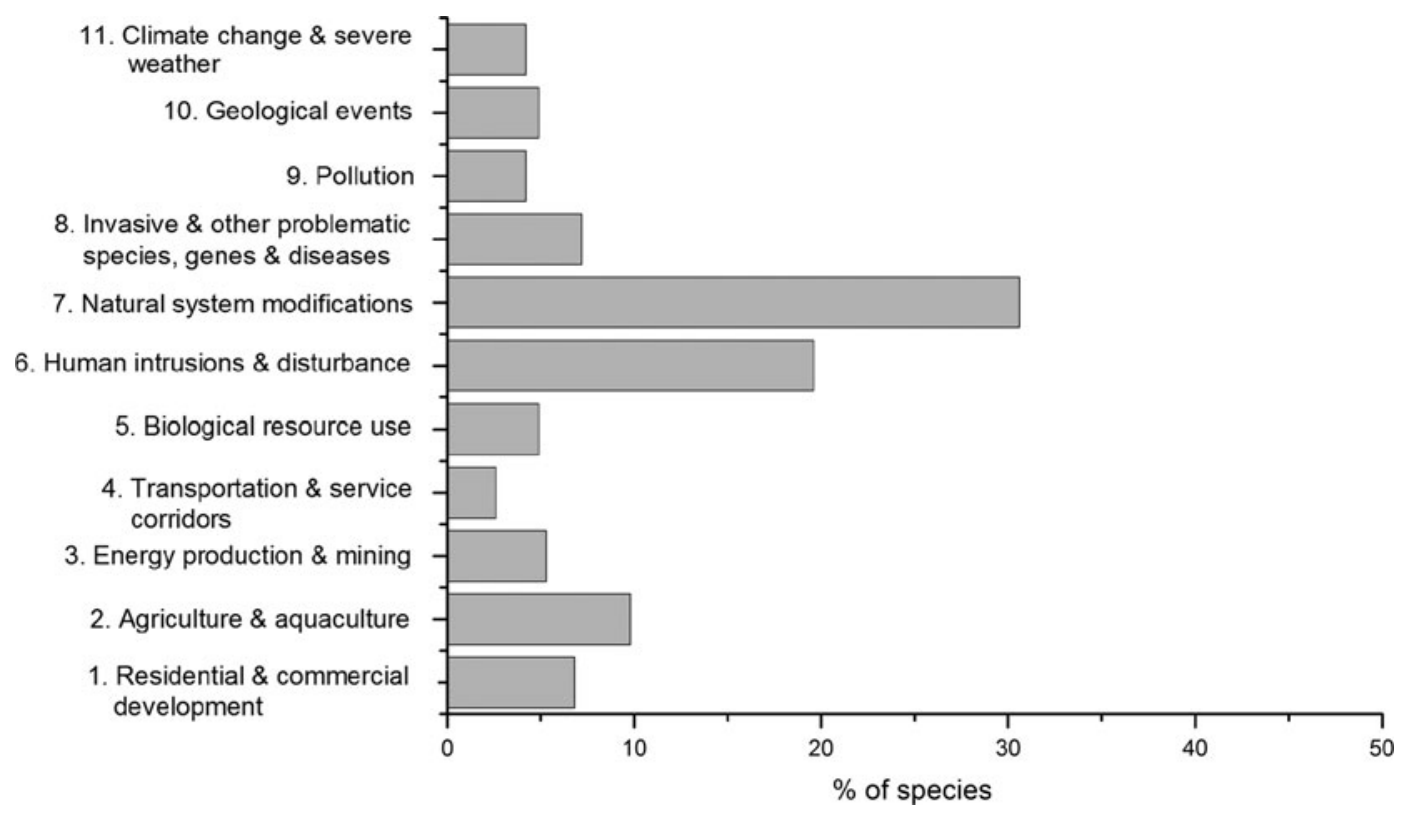

FIG. 1 The percentage of 203 policy species of the Italian flora subject to each major threat category according to the IUCN Threats Classification Scheme (version 3.2; IUCN, 2012c).

(Gentili et al., 2010; Abeli et al., 2013) and the careful use of plant material, such as translocations (Godefroid et al., 2011b; Maschinski \& Haskins, 2012; Cogoni et al., 2013; Rossi et al., 2013b; Soorae, 2013). Conservation priorities and intervention strategies should be established at the national scale, as has been accomplished in some cases at the regional level in Italy (e.g. Sardinia; Bacchetta et al., 2012). The results of this assessment can be used to determine those species at the brink of extinction (Critically Endangered, e.g. Isoetes malinverniana Ces. \& De Not., Abeli et al., 2012; Barni et al., 2013), for which conservation is a pressing need, and to define specific plans, including both in situ and ex situ measures (e.g. Devillers-Terschuren, 1999; Grunau et al., 2011).

At present EU member states are required to draw up a report every 6 years on the conservation status of species and habitats listed in the Habitats Directive (ex art. 17). However, for those species at the brink of extinction, monitoring activities should be more frequent (at least every 2 years) and conservation actions should start immediately for all species assigned to a threat category (including Vulnerale and Endangered).

As demonstrated by Stanton et al. (2015) and Akçakaya et al. (2014) for species threatened by climate change, conservation actions should begin as soon as a species is listed as Vulnerable, because $50 \%$ of species have gone extinct within 20 years of becoming categorized as Critically Endangered. Protocols for listing threatened species are useful for forecasting extinctions (Keith et al., 2004) and in this sense the results presented here are alarming.

In conclusion, the current legal protection is insufficient to guarantee plant conservation, and Red Lists are a valuable tool to focus the attention of policymakers and conservation planners, as well as the general public, on the most threatened species. However, there is an urgent need for conservation action and management strategies. Otherwise we risk losing a large portion of plant diversity within the next few decades.

\section{Acknowledgements}

The authors are grateful to the Italian Ministry for the Environment, Land and Sea, Directorate for Nature Protection, for its financial support of the Red List assessment programme described here, and to the secretariat of the Italian Botanical Society for its support during the process. We thank the more than 200 Italian botanists who provided field data, without whose collaboration these assessments would have been impossible.

\section{References}

Abeli, T., Barni, E., Siniscalco, C., Amosso, C. \& Rossi, G. (2012) A cost-effective model for preliminary site evaluation for the reintroduction of a threatened quillwort. Aquatic Conservation: Marine and Freshwater Ecosystems, 22, 66-73.

Abeli, T., Orsenigo, S., Ardenghi, N.M.G., Lucassen, E.C.H.E.T. \& SMOLDERS, A.J.P. (2013) Hydrochemical characterization of a stand of the threatened endemic Isoëtes malinverniana. American Fern Journal, 103, 241-244.

AkçaKaya, H.R., Butchart, S.H.M., Watson, J.E.M. \& Pearson, R.G. (2014) Preventing species extinctions resulting from climate change. Nature Climate Change, 4, 1048-1049. 
Bacchetta, G., Fenu, G. \& Mattana, E. (2012) A checklist of the exclusive vascular flora of Sardinia with priority rankings for conservation. Anales del Jardín Botánico de Madrid, 69, 81-89.

Barni, E., Minuzzo, C., Gatto, F., Lonati, M., Abeli, T., Amosso, C. et al. (2013) Estimating influence of environmental quality and management of channels on survival of a threatened endemic quillwort. Aquatic Botany, 107, 39-46.

Bilz, M., Kell, S.P., Maxted, N. \& Lansdown, R.V. (2011) European Red List of Vascular Plants. Publications Office of the European Union, Luxembourg.

Butchart, S.H.M., Stattersfield, A.J. \& Brooks, T.M. (2006) Going or gone: defining 'Possibly Extinct' species to give a truer picture of recent extinctions. Bulletin of the British Ornithologists' Club, 126, 7-24.

Cañadas, E.M., Fenu, G., Peñas, J., Lorite, J., Mattana, E. \& BACchetta, G. (2014) Hotspots within hotspots: endemic plant richness, environmental drivers, and implications for conservation. Biological Conservation, 170, 282-291.

Cogoni, D., Fenu, G., Concas, E. \& Bacchetta, G. (2013) The effectiveness of plant conservation measures: the Dianthus morisianus reintroduction. Oryx, 47, 203-206.

Condé, S., Jones-Walters, L., Torre-Marin, A. \& Romão, C. (2010) EU 2010 Biodiversity Baseline. EEA Technical report 12/2010, Copenhagen, Denmark.

Conti, F., Abbate, G., Alessandrini, A. \& Blasi, C. (2005) An Annotated Checklist of the Italian Vascular Flora. Palombi Editori, Rome, Italy.

Conti, F., Alessandrini, A., Bacchetta, G., Banfi, E., Barberis, G., Bartolucci, F. et al. (2007) Integrazioni alla checklist della flora vascolare italiana. Natura Vicentina, 10, 5-74.

Conti, F., Manzi, A. \& Pedrotti, F. (1992) Libro Rosso delle Piante d'Italia. Ministero Ambiente, WWF Italia, Società Botanica Italiana, Florence, Italy.

Conti, F., Manzi, A. \& Pedrotti, F. (1997) Liste Rosse Regionali delle Piante d'Italia. WWF Italia, Società Botanica Italiana, Florence, Italy.

Crain, B. \& White, J. (2013) A checklist and floristic summary of the vascular plants of Napa County, California. Phytotaxa, 95, 1-50.

Crain, B., White, J. \& SteinberG, S. (2011) Geographic discrepancies between global and local rarity richness patterns and the implications for conservation. Biodiversity and Conservation, 20, 3489-3500.

De Grammont, P.C. \& Cuarón, A.D. (2006) An evaluation of threatened species categorization systems used on the American continent. Conservation Biology, 20, 14-27.

de Montmollin, B. \& Strahm, W. (eds) (2005) The Top 50 Mediterranean Island Plants: Wild Plants at the Brink of Extinction, and What is Needed to Save Them. IUCN/SSC Mediterranean Islands Plant Specialist Group. IUCN, Gland, Switzerland and Cambridge, UK.

Devillers-Terschuren, J. (1999) Action Plan for Cypripedium calceolus in Europe. Council of Europe Publishing, Strasbourg, France.

Fenu, G., Mattana, E. \& Bacchetta, G. (2011) Distribution, status and conservation of a Critically Endangered, extremely narrow endemic: Lamyropsis microcephala (Asteraceae) in Sardinia. Oryx, $45,180-186$.

Fenu, G., Mattana, E. \& Bacchetta, G. (2012) Conservation of endemic insular plants: the genus Ribes L. (Grossulariaceae) in Sardinia. Oryx, 46, 219-222.

Foggi, B., Viciani, D., Baldini, R.M., Carta, A. \& Guidi, T. (2015) Conservation assessment of the endemic plants of the Tuscan Archipelago, Italy. Oryx, 49, 118-126.
Gärdenfors, U., Hilton-Taylor, C., Mace, G.M. \& Rodríguez, J.P. (2001) The application of IUCN Red List criteria at regional levels. Conservation Biology, 15, 1206-1212.

GARGAno, D. (2011) Verso la redazione di nuove Liste Rosse della flora d'Italia: una griglia standard per la misura dell'Area of Occupancy (AOO). Informatore Botanico Italiano, 43, 455-458.

Gentili, R., Abeli, T., Rossi, G., Li, M., Varotto, C. \& Sgorbati, S. (2010) Population structure and genetic diversity of the threatened quillwort Isoëtes malinverniana and implication for conservation. Aquatic Botany, 93, 147-152.

Gentili, R., Rossi, G., Abeli, T., Bedini, G. \& Foggi, B. (2011) Assessing extinction risk across borders: integration of a biogeographical approach into regional IUCN assessment? Journal for Nature Conservation, 19, 69-71.

Godefroid, S., Rivière, S., Waldren, S., Boretos, N., Eastwood, R. \& VAnderborght, T. (2011a) To what extent are threatened European plant species conserved in seed banks? Biological Conservation, 144, 1494-1498.

Godefroid, S., Piazza, C., Rossi, G., Buord, S., Stevens, A.-D., Aguraiuja, R. et al. (2011b) How successful are plant species reintroductions? Biological Conservation, 144, 672-682.

Grunau, L., Handwerk, J. \& Spackman-Panjabi, S. (eds) (2011) Colorado Wildlife Action Plan: Proposed Rare Plant Addendum. Colorado Natural Heritage Program for Rare Plant Conservation Initiative, Colorado State University, Fort Collins, USA.

IUCN (2012a) Guidelines for Application of IUCN Red List Criteria at Regional and National Levels: Version 4.o. IUCN Species Survival Commission. IUCN, Gland, Switzerland. Http://www.iucnredlist. org/documents/reg_guidelines_en.pdf [accessed 2 January 2015].

IUCN (2012b) IUCN Red List Categories and Criteria: Version 3.1. Second Edition. IUCN Species Survival Commission. IUCN, Gland, Switzerland. Http://jr.iucnredlist.org/documents/redlist_cats_crit_ en.pdf [accessed 2 January 2015].

IUCN (2012c) Unified Classification of Direct Threats: Version 3.2. Http://www.iucnredlist.org/technical-documents/classificationschemes/threats-classification-scheme [accessed 2 January 2015].

IUCN (2013) Guidelines for Using the IUCN Red List Categories and Criteria. Version 10. Standards and Petitions Subcommittee. Http:// www.iucnredlist.org/documents/RedListGuidelines.pdf [accessed 2 January 2015].

KÅlÅs, J.A., Viken, Å., Henriksen, S. \& Skjelseth, S. (eds) (2010) The 2010 Norwegian Red List for Species. Norwegian Biodiversity Information Centre, Trondheim, Norway.

Keith, D.A., McCarthy, M.A., Regan, H., Regan, T., Bowles, C., Drill, C. et al. (2004) Protocols for listing threatened species can forecast extinction. Ecology Letters, 7, 1101-1108.

Király, G. (ed.) (2007) Vörös Lista. A magyarországi edényes flóra veszélyeztetett fajai. (Red list of the vascular flora of Hungary). Saját kiadás, Sopron, Hungary.

Laguna, E., Ballester, G., Ranz, F.J., Fabregat, C., Olivares, A., Serra, L. et al. (2003) Valencian micro-reserves experience. A practical approach managing small protected, natural areas. In Microhabitats Forum 2002-2003, Consellería de Territorio y Vivienda. Generalitat Valenciana, Valencia, Spain.

Maschinski, J. \& Haskins, K.E. (eds) (2012) Plant Reintroduction in a Changing Climate: Promises and Perils. Island Press, Washington, DC, USA.

Mattana, E., Fenu, G. \& Bacchetta, G. (2012) Regional responsibility for plant conservation: the 2010 GSPC Target 8 in Sardinia. Plant Biosystems, 146, 649-653.

Médail, F. \& QuéZel, P. (1999) Biodiversity hotspots in the Mediterranean Basin: setting global conservation priorities. Conservation Biology, 13, 1510-1513. 
Moreno SAIZ, J.C. (2008) Lista roja 2008 de la flora vascular Española. Ministerio de Medio Ambiente y Medio Rural y Marino, Madrid, Spain.

Moreno Saiz, J.C., Domínguez lozano, F. \& Sainz Ollero, H. (2003) Recent progress in conservation of threatened Spanish vascular flora: a critical review. Biological Conservation, 113, 419-431.

Peruzzi, L. (2010) Checklist dei generi e delle famiglie della flora vascolare italiana. Informatore Botanico Italiano, 42, 151-170.

Rassi, P., Hyvärinen, E., Juslén, A. \& Mannerkoski, I. (eds) (2010) Suomen lajien uhanalaisuus (The Red List of Finnish Species). Ministry of the Environment. Edita Ltd., Helsinki, Finland.

Rodrigues, A.S.L., Pilgrim, J.D., Lamoreux, J.F., Hoffmann, M. \& Brooks, T.M. (2006) The value of the IUCN Red List for conservation. Trends in Ecology \& Evolution, 21, 71-76.

Rossi, G., Montagnani, C., Gargano, D., Peruzzi, L., Abeli, T., Ravera, S. et al. (eds) (2013a) Lista Rossa della Flora Italiana. 1. Policy Species e altre specie minacciate. Comitato Italiano IUCN e Ministero dell'Ambiente e della Tutela del Territorio e del Mare. Stamperia Romana, Rome, Italy.

Rossi, G., Amosso, C., Orsenigo, S. \& A beli, T. (2013b) Linee Guida per la traslocazione di specie vegetali spontanee. Quaderni di Conservazione della Natura, 28, MATTM - Ist. Sup. Protezione e Ricerca Ambientale (ISPRA), Rome, Italy.

Rossi, G., Montagnani, C., Abeli, T., Gargano, D., Peruzzi, L., FenU, G. et al. (2014a) Are Red Lists really useful for plant conservation? The New Red List of the Italian Flora in the perspective of national conservation policies. Plant Biosystems, 148, 187-190.

Rossi, G., Orsenigo, S., Dhital, D., Shrestha, S., Shrestha, B.B., Maharjan, S.R. et al. (2014b) Ex situ plant conservation initiative in developing country: Nepal as a case study. Plant Biosystems, 148, 565-569.

Soorae, P.S. (ed.) (2013) Global Re-introduction Perspectives: 2013. Further Case Studies From Around the Globe. IUCN/SSC
Re-introduction Specialist Group, Gland, Switzerland, and Environment Agency-Abu Dhabi, UAE.

Stanton, J.C., Shoemaker, K.T., Pearson, R.G. \& Akçakaya, H.R. (2015) Warning times for species extinctions due to climate change. Global Change Biology, 21, 1066-1077.

Trouwborst, A. (2009) International nature conservation law and the adaptation of biodiversity to climate change: a mismatch? Journal of Environmental Law, 21, 419-442.

Tsintides, T., Christodoulou, C.S., Delipetrou, P. \& Georghiou, K. (2007) The Red Data Book of the Flora of Cyprus. Cyprus Forestry Association, Lefkosia, Cyprus.

Turis, P., Kliment, J., Ferákovâ, V., Dítě, D., Eliáš, P., Hrivnák, R. et al. (2014) Red List of vascular plants of the Carpathian part of Slovakia. Thaiszia Journal of Botany, 24, 35-87.

UneP (United Nations Environment Programme) (2002) Global Strategy for Plant Conservation. The Secretariat of the Convention on Biological Diversity, Montreal, Canada.

\section{Biographical sketches}

The authors are all members of the Italian Botanical Society (SBI), founded in Florence in 1888. The SBI is organized into working groups dealing with specific areas of interest. The activities of the Working Group for Nature Conservation are focused on issues inherent to the preservation of the Italian floristic heritage. Since 2006 the Working Group for Nature Conservation, supported by other groups of the SBI (Floristic, Lichenology, Bryology, and Mycology), has promoted the development of a new and comprehensive Red List of the Italian Flora based on the most recent IUCN protocol, and has collaborated with IUCN specialists by contributing to the European Red List and other continent-wide assessment programmes. 